\title{
The Rise Of Person-Based Politics In The New Democracies: The Czech Republic And Slovenia
}

\author{
LADISLAV CABADA, MATEVŽ TOMŠIČ
}

$\frac{\text { DE }}{\mathrm{G}} \stackrel{\substack{\text { DE GRUYTER } \\ \text { OPEN }}}{ }$

Politics in Central Europe (ISSN: 1801-3422)

Vol. 12, No. 2

DOI: 10.1515/pce-2016-0011

\begin{abstract}
In the article, the authors address certain recent political developments in two former communist countries, the Czech Republic and Slovenia. They focus on the rise of personalized politics, i.e. the type of political conduct that is driven predominantly by the personal character of political leaders (much more than by programs and ideologies). Specifically, the authors look at the weak political partisanship in East-Central Europe as one of the key factors triggering person-based politics. They find that personalized leadership has divergent consequences for political life in a democratic polity. It is very effective in mobilizing mass support as well as in overcoming many organizational obstacles. However, its influence on the quality of the democratic process is questionable.
\end{abstract}

Key words: Czech Republic, Slovenia, strong leaders, person-based politics, new democracies

\section{Introduction}

The "personalization of politics" is a topic that has been gaining importance in scholarly literature and research. Although some authors claim that empirical evidence on this phenomenon is mixed, at best (Kriesi 2011), and it depends on the institutional setting of the particular polity (Kaase 1994), it is hard to deny that personal traits of political leaders play an increasingly important role in the political life of contemporary democracies (Van Zoonen - Holz-Bacha 2001), which is referred to by some as the presidentalization of politics (Poguntke and Webb 2005a). Namely, political space in contemporary democracies has been undergoing a profound change over last few decades, which applies in 
particular to developments in political parties' organizational structures and in the way in which they function, as well as a change in the mechanisms used to mobilize political support and in establishing a link between the parties and their constituencies.

The political life of contemporary democracies is characterized by several features that provide fertile conditions for a personalization of that life. We can talk about the diminishing importance of social cleavages, which crystallized during the process of modernization of Western societies and served as the basis for the formation of the modern political party system (Inglehart 1990). This is related to individualization, in terms of the weakening of classical political identities (class, nation, religion, ideology) (Beck - Beck-Gernsheim 2002, Genov 2010). The result is that the position of political parties as organizational vehicles of collective action and social choice is weakened (Kitschelt 2001), and agencies are channeled that represent and create a link between society and government institutions (Sartori 1976). The shift toward personalized politics has been going on over the last few decades. The personalities of various politicians has contributed to the emergence of new political parties based on strong leaders (Bossi, Le Pen, Furtuyn, etc.) as well as to the revival of some traditional parties (one example is the role of Tony Blair in the rise of New Labour) (Tomšič - Prijon 2013).

The rise of person-based politics is even more evident in the new democracies from Central and Eastern Europe. It is a reflection of destabilization of political space and deconsolidation of political parties. This also applies to the Czech Republic and Slovenia, two countries that belong to the group of most consolidated new democracies, once considered to have some of the most stable party systems in the region. This paper will analyze 1) the rise of new politics in both countries, i.e. the type of political conduct that is driven predominantly by the personal character of political leaders (much more than by programs and ideologies), 2) its roots and manifestations, as well as 3) the consequences for the functioning of democracy. According to the authors, personalized leadership has divergent consequences for political life in a democratic polity. It is very effective in mobilizing mass support, overcoming many organizational obstacles. However, its influence on the betterment of the democratic process is questionable.

We will first address the role personalities play in contemporary democracies and how they impact the functioning of political parties. Later, we will look at the specifics of political developments in Central and Eastern European countries, focusing on the two countries under consideration, where special attention is devoted to a comparison of the manifestations of personalized politics and the factors that have contributed to its proliferation. And in the closing section, we explain the consequences of these developments on the quality of democracy in the new democracies. 


\section{Personalized politics}

The personalization of politics in modern democracies is a phenomenon that was first indicated within the social sciences some three decades ago. We point to Margaret Thatcher as one of the first Western politicians who showed a strong personal impetus within the party and the government. Nevertheless, only with the development of new mass communication tools (TV and especially new media accessible through the Internet) were modern democracies challenged by this new phenomenon, in a general manner. This development affected both political parties as well as executive bodies and, in some ways, also the type of political regime and politics as a whole. We focus in our analysis mainly on party system and party-voter development and, above all, leader-party and leader-voter relations. To better understand the basic concepts related to personalization of politics-and related concepts and terms-we will briefly present the contemporary discussion on personalization within political science.

In his brand new analysis of oligarchization, personalization and presidentialization of politics, Jurek (2014: 29-30) presents the interesting case study of the personalization processes in Israel (Rahat - Sheafer 2007), which recognizes three different types of personalization-institutional, media, and behavioral. In his opinion, it is the behavioral component of the process of personalization of politics that must be examined. Based on this aspect, he understands personalization of politics as a "trend occurring during the last decades within the democratic political environment that is based on strengthening the role of individual actors (party leaders, candidates, mandate holders) in political life" (Jurek 2014: 33).

Poguntke and Webb in their influential book (2005) also discuss the strengthened position and role of political and party leaders in contemporary modern democracies. They argue that "perceptions of the personalization, and in particular the 'presidentialization' of politics have become more widespread in recent years, regardless of formal constitutional characteristics." They point to prime ministers and party leaders such as Tony Blair, Gerhard Schröder, and Silvio Berlusconi (Poguntke - Webb 2005a: 1). Through their analysis they have delineated their concept of the three faces of presidentialization. For our article the first concept-that of the executive face combined with a discussion about the type of political regime-seems obsolete. On the other hand, the next two faces-the party and electoral faces-might be useful as a platform for the operationalization of the term "personalized politics".

Poguntke and Webb (2005a: 9) utilize the party face to present the personalization of politics as a "shift in intra-party power to the benefit of the leader.

“... party activists and factional leaders cease to be the decisive power base of party leaders; rather, claims to leadership rest on personalized mandates. This 
is likely accompanied by the shift toward plebiscitary modes of communication and mobilization... Increasingly, the leader seeks to by-pass the sub-leaders and activist strata of the party and communicates directly with members (or even voters)... Probably most relevant in this regards is the shift toward candidate-centered electioneering."

The authors argue that the result of this type of development results in a concentration of power in the leader's office.

In their discussion of the electoral face, which is logically strongly linked with the intra-party development discussed previously, the authors firstly stress the "growing emphasis on leadership" that appears in electoral campaigns. Furthermore, news coverage of these campaigns is such "that the media coverage of politics focuses more on leaders." Finally, talking about the general electoral processes, the "growing significance of leader effects in voting behavior" might be observed (Poguntke - Webb 2005a: 10).

Poguntke and Webb (2005a: 13-16) present the internationalization of politics, the growth of the state, the changing structure of mass communication (most authors stress the role of electronic media, cf. Jurek 2014: 28), and the erosion of traditional social cleavage politics as the main reasons for this development. Similarly, Blondel and Thiébault (2010: 17-18) connect the personalization of politics with the growing individualization in society and weakening of traditional societal bonds and cleavages. This point seems to be clearly connected with the party and electoral face. As Poguntke and Webb summarize, "the clear-cut orderliness of political competition based on the conflict of social group ideologies... seems to be disappearing in modern democracies... As consequence... factors such as the personal qualities of actual or prospective heads of governments may become relatively more important for the conduct of election campaigns."

Jurek (2014:35-36) assumes that the personalization concepts center around three groups of individual political actors:

1. individual politicians, regardless of their position (party officials, candidates for directly elected posts, deputies, members of the government, etc.)

2. party leaders, chairpersons of political parties

3. executive leaders

The third category seems to be deeply linked with the research of presidentialization; in this sense presidentialization might be-within the behavioral typeunderstood as a sub-type of personalization. This is why we are also utilizing the analytical framework of Poguntke and Webb. Nevertheless, in our analysis we will concentrate only on the second category, i.e. party leaders. 
Naturally, the strengthening role of the party leader also applies to the development of political parties as such. We do not have room here for a comprehensive discussion on this issue but would like to mention the discussion about the new types of political parties-cartel parties (Katz - Mair 1995) and business firm parties (Krouwel 2006). In both cases we must note the weakening bonds to the party base as an important characteristic and also the growing tendency to outsource services not just for electoral campaigns but also for program and policy formulation (cf. Cabada 2014).

To sum up, personalized politics means, "first and foremost," as Poguntke and Webb (2005b: 352) stress, the "weakening of party as a collective actor in modern democracies." Political parties "have maintained their central role as a mechanism for elite selection... However, they have been substantially challenged as actors aggregating interests... shaping policy outcomes or controlling political communications." For the party leader his own party is less important than his office. To communicate with party members and voters, leaders also often use the methods of "direct democracy."

"Membership ballots and referenda... are more often than not initiated and
controlled by leaders... In a nutshell, plebiscitary features of modern demo-
cratic politics tend to enhance, rather than limit, elite autonomy by providing
leaders with an additional power resource" (Poguntke - Webb 2005b: 354-5).

Nevertheless, Jurek (2014: 25-26) doubts that the strengthening of a party's leader automatically brings the weakening of the political party itself. We fully agree with those doubts. On the other hand, overparticization in the new democracies (we explain the concept below) would mean that it is even easier for party leaders to have developed personalized political strategies. This is, why within CEE party systems with low and even sinking party membership ${ }^{1}$ personalized politics based on business firm parties or franchise parties are successful. Those parties see voters as consumers of politics and prefer an office-seeking strategy; they have a strong tendency to outsource party activities and have the strong, personal leadership of a "political entrepreneur" (the party almost without members) (cf. Hloušek 2012; Hopkin - Paolucci 1999; Krouwel 2006; Meguid 2005; Tavits 2008; or Wagner 2012).

As Hloušek (2012: 324) mentions, business firm parties "are partially similar with the previous development types of political parties, but they differ in some important aspects. Compared with the cartel parties they benefit from the private sector sources, compared with the catch-all parties they do not target the interest groups that would represent concrete ideas." Business-firm parties-and the more general niche parties-are very flexible in their search for

1 Innes (2002) labelled the East Central European mainstream political parties "instant catch-all parties." 
themes and strategies; on the other hand, they are also implicitly fragile due to their dependence on changeable electoral support and the attention given by the media to the parties and their leaders (Hloušek 2012: 324; cf. Carty 2004: 20-21). Let us add that some authors (cf. Olteanu and de Nève, not dated) argue that the specific position of political entrepreneurs originates in their own big firms; they have referred to political "parties" created by such entrepreneurs as businessman parties. These parties evince an "elite-oriented organizational structure, the wealth of resources of their founders, a manifesto and an ideology, which is based on the assumption that economy precedes politics, and, moreover, an exclusive access to the media." Naturally, such parties are one-person structures, i.e. almost completely personalized actors.

\section{Characteristics of post-communist party systems}

The main aim of the post-communist transformation was to carry out political, economic, social and cultural modernization, and thus to overcome their status of European (semi) periphery, which has characterized a vast majority of these societies for centuries (Janos 2000). This refers also to the establishment of a democratic system of governance. In this regard, some of those countries-new members of the EU from East-Central Europe-could be labeled as consolidated democracies since they managed to establish the key institutional mechanisms necessary for a successful democratic life (cf. Adam et al. 2005).

In formal terms, party systems of former communist countries resemble those in the West. The parties have also largely adopted the basic organizational principles and style employed by their counterparts in the established democracies (van Biezen 2003). Many of them are members of European party associations.

However, the social basis that determines their structure is different in some key aspects and is related to the specifics of the modernization process. As stated by Evans and Whitefield (1993: 522), "communism deprived individuals of institutional or social structured identities from which to drive political interests, other than those of the nation or mass society." Political space in most of these countries is still characterized by relative instability and volatility. This is mostly the consequence of the weak profiled identity of many political parties, which has been causing them considerable trouble in establishing a stable electoral base (Baylis 1998). This is reflected in relatively low party membership and weak linkages between party elites and their constituencies (Lewis 2001). Political parties in post-communist countries, when compared to their counterparts in established democracies of Western Europe, lack mass membership-certain exception are some post-communist or former satellite parties (Cabada, 2013c: 81).

The ideological focus or self-identification of particular political parties in East-Central Europe is often very shallow and formal. Their programs are often 
very vague and incomprehensible. They are keen to switch their policy orientations when expecting political benefits from doing so. Some of them have experienced significant transition in terms of ideological profile. ${ }^{2}$ Ideological emptiness particularly holds for niche parties, which are more present in this region than in Western Europe. In this regard, they differ with their Western counterparts, which are often very coherent and focused in terms of ideological orientations (the Five Star Movement in Italy is one exception in this regard). Unlike them, they build their public appeal with general criticism of established political parties and the character of their leaders. The irony is that these parties can easily transform themselves into a mainstream one (examples are SMER in Slovakia, GERB in Bulgaria, ANO 2011 in the Czech Republic, or Positive Slovenia in Slovenia) (Cabada 2013a: 16-17).

Political actors in general and political parties in particular are often criticized for their aspirations of control over various social systems, mostly the ones that could contribute to retaining or obtaining positions of power. For example, Attila Agh (1996: 55) points to overparticization, which refers to the aspirations of political parties to exclude other actors from political life. This partitocracy is less an expression of the parties' strength but more of their weakness, i.e. their weak intellectual and organizational potential (they try to compensate by borrowing resources from other areas). In any case, such practices strongly contribute to parties' low voter confidence and bad public image, regardless their ideological orientation. This created space for a different, more personalized approach in political contests.

Weak links between parties and society, coupled with a lack of democratic experience, as well as the unresponsive and irresponsible conduct of political elites, result in a high level of distrust in political parties in the eyes of the public. The rather low confidence in political parties is also characteristic for established democracies but is considerably more pronounced in former communist countries. We can speak about strong "anti-party sentiments" (Fink-Hafner 1995). All this affects political participation. Voter turnout is considerably lower on average in Western Europe and is even decreasing in some new democracies (for example, in Slovenia).

As we can see, political life of the new democracies is characterized by a number of features that provide fertile ground for a personalization of political life. Low trust of the citizenry toward traditional political agents, especially political parties, opens the door to non-party politics, which is based not on a coherent ideology or party program but on the personal traits of particular political ac-

2 One clear example is the current ruling Hungarian party Fidesz which evolved from a liberal-centrist oriented party to a strongly conservative and nationalist one. Some of its orientation has changed completely; for example, the attitude toward Russia: once fiercely anti-Russia it is now pro-Russian. Interestingly, all this happened under the same leader, Victor Orban, which testifies to the flexibility of his personal affiliations. 
tors. In such circumstances, the personal appeal of political leaders is often the one that comes into play since it can override party weaknesses (as we will see in the case of Slovenia, the political status of many parties greatly depends on their leaders). Many parties, radical as well as mainstream, had strong personalized players, like Victor Orban's Fidesz in Hungary or Law and Justice of the Kaczynski brothers in Poland. Moreover, many politicians build their appeal on anti-party or even anti-political platforms, which was the case with Tyminski ${ }^{1}$ in Poland in the early 1990s or Uspaskich ${ }^{2}$ in Lithuania in the mid-2000s. Both were political outsiders who entered political space from the business sphere and who, during their campaigns, severely criticized already-established political parties, proclaiming a different, more managerial approach in their governance conduct, which would wither away the defects of established politics.

High volatility is a frequent occurrence in the highly personalized new parties, which can gain success in one election but typically, after a short period, become marginalized or even disappears from political scene, being replaced by newer parties (Haughton - Deegan-Krause 2015). We have even witnessed political destabilization in countries that were considered to have rather stable political and party systems-such as the situation in the Czech Republic and Slovenia. In following sections, we will discuss the rise of personalized-type politics in both countries. We will ascertain its origins, causes for its appearance, as well as the main characteristics and consequences of these political developments.

\section{The rise of new politics in the Czech Republic and Slovenia}

\section{The Czech Republic}

During the 1990s and 2000s, the Czech party system was usually described as relatively stable (Cabada - Krašovec 2012). Indeed, we could register opinions that indicate the Czech party system as a type between moderate and polarized pluralism, or-better said-about the oscillation between these two types (Havlík - Hloušek 2013). In the first half of 1990 the reason for this indication was the presence of two anti-system parties in the parliament-the Republicans on the right and the nostalgic Communist Party of Bohemia and Moravia (KSČM) on the left. Since the first half of the 1990s the important position and role of the radical KSČM and the thoughts about the left-oriented government, including the Social Democrats (ČSSD) and also the Communist Party were the main reason for doubts whether the party system should be evaluated as limited or extreme pluralism (Hloušek and Pšeja 2009: 516). ${ }^{3}$

3 Cabada, Hloušek and Jurek (2013) indicate than during periods of intensified cooperation between the ČSSD and KSČM a moderate pluralism could be seen, while the parties' dance to gain more strength moved the party system toward a more polarized situation. 
Talking about the cleavages in Czech society, two key ones are apparent. On one side there is a socio-economic cleavage, which has dominated from the very beginning of the transition (Hloušek - Pšeja 2009; Cabada, Hloušek - Jurek 2013). Nevertheless, we should not forget the also important and still present anti-Communism vs. Communism cleavage that, in the last few years, has been losing significance (Hloušek - Kopeček 2012; Krašovec - Cabada 2013). Based on these main cleavages, five relevant parties arose after the 1998 elections, and they continued to remain significant for more than a decade.

Signs of personalized politics and continued personalization have been present within the Czech parties and, more generally the political system as a whole, since the beginning of the transition (the most important being the ideological-political discussion between Václav Havel and Václav Klaus). At the party level, especially the leaders of the two catch-all parties-the Civic Democrats (ODS) and, after its consolidation in 1993-1995 the ČSSD-developed their approach toward voters and within the party in a clearly personalized form. It was possible to discern a stabilized personal configuration during the 1990s in the form of the ODS's leader Klaus against the leader of the ČSSD, Miloš Zeman. This constellation returned in the second half of the 2000s when Klaus's successor, Mirek Topolánek, a strong opposition leader, was challenged by the new ČSSD leader, Jiř́i Paroubek. ${ }^{4}$

After Paroubek's ascension, Czech politics became strongly personalized around him and Topolánek. This was visible during the electoral campaign, including the media's coverage of it, and also within the parties, both before and after the 2006 elections. Both parties posted their best-ever electoral resultsthe ODS (35.4 percent) and ČSSD (32.3 percent)-indicating that society also understood the elections to be primarily a duel of the parties or their leaders (Vodička - Cabada 2011: 258-262). In addition to these two catch-all parties, new challengers began to promote themselves through their connections with their leaders/father grounders. This was the case of the hard-line anti-European right with the chairwoman Jana Bobošíková (Sovereignty Jana Bobošíková Bloc) as well as the populist movement supporting the presidential aspirations of former ČSSD head and prime minster, Zeman-the Party of Civic Rights-Zemanists (SPOZ). Clear attributes of personalized politics were also apparent in the new centrist party: Tradition, Responsibility, Prosperity 09 (TOP09), initially led by Czech icon, longtime friend and close collaborator of Václav Havel-and his minister of foreign affairs (2007-2009)-the "prince," Karel Schwarzenberg.

The weakening of both catch-all parties, the ODS and ČSSD, which had dominated Czech politics since 1992, partly resulted from the clash between the

4 Paroubek earned the moniker "Bulldozer," thanks to his style towards the party, both in the coalition government and toward society. During one parliamentary debate he referred to himself as "infallible" and defended the cooperation with the KSČM by stating that his politics are right and must be enforced, even if it were with the support of "Martians." 
parties' two strong leaders, Topolánek and Paroubek, from 2005 to 2010. This matter of fact was clearly evident in the 2010 parliamentary elections, when two brand new political parties entered the Parliament-TOP09 as well as Public Affairs (VV). The ODS and ČSSD lost about 40 percent of voters; the Christian Democrats (KDU-ČSL) and the Green Party (SZ) failed in the election with less than 5 percent of the votes, i.e. under the legal threshold. As the only stable party the KSČM came out from the election as successful, which also brought the end of Paroubek as ČSSD leader (Topolánek had resigned as ODS leader before the elections because of a scandal that arose after an interview where he made several controversial statements, such as claiming both gay and Jewish people lacked the integrity of moral character, among other things). Because of future events, the failure of Zeman's SPOZ in this election must also be mentioned.

The year 2010 brought the new political parties their first taste of success. This was based fully or, for some parties at least partially, on personalized politics. As an example of the latter, TOP09's campaign was more or less tied to the personage of Schwarzenberg. Nevertheless, VV represents the most visible success; it made use of a niche marketing strategy and a short intensive campaign with some very specific attributes.

VV was established in 2001 as local initiative. The party's first breakthrough came in the form of the election of its new leader, the well-known journalist, Radek John, in June 2009 in cooperation with some other prominent Czech personalities. Nevertheless, the main person within the party was the owner of the biggest private security agency in the Czech Republic Vít Bárta. He was and is very controversial, seemingly applying tools against political opponents that are more commonly used in the sphere of secret services (Bureš 2012:145). The party presented itself as a pragmatic and slightly populist alternative to the "corrupt dinosaurs." In the 2010 elections VV got 10.9 percent of the vote and 24 of a total 200 mandates in the Chamber of Deputies. In the process of forming the new government, VV became the most important party, with unlimited coalition potential. The party's leaders occupied key ministries. It soon became apparent that all these offices (except for the Ministry of Regional Development) were de facto managed directly by Bárta, himself the minister of transport. (Cabada 2013b: 41).

Negotiations over the governmental program were a failure from the start when VV leaders decided that they wanted a more left-oriented position in the neoliberal government. The discussions exposed VV as programmatically unclear (Bureš 2012: 148, based on Hloušek 2012: 333); in the case of VV as the party of business, an official, coherent ideology or program was totally absent; the party considered voters as consumers.

Bárta tried to relaunch the party as fully populist and in cooperation with new a personalized party-Tomio Okamura's Dawn of Direct Democracy (Úsvit prŕmé demokracie Tomia Okamury). The key figure of this new project, again search- 
ing for a niche in the Czech political market, was Tomio Okamura, a travel and gastronomy entrepreneur and spokesman for the Association of Czech Travel Agencies (AČCKA). Okamura won a seat as an independent candidate in the 2012 Senate elections, representing the southeastern Moravian region of Zlín, and later he founded his party with only nine members. The most visible feature of his party's program was the promise of "direct democracy", which included changes in the law to provide for the possibility to remove from office politicians, clerks, judges, etc. In addition to this issue the party-and Okamura as the sole visible face-developed a populist rhetoric that called for the protection of "common citizens" against the political elite, as well as against "anti-social" citizens and migrants. In the parliamentary elections in October 2013 Dawn won 6.88 percent of the vote and 14 of the 200 mandates. During the next 18 months Okamura did everything to close the door to new members. In the end such behavior-together with misuse of state budget-provided funds for the party-resulted in an open revolt within the party against Okamura.

As already mentioned, the $\mathrm{SPOZ}^{5}$ is an important example of personalized politics. At the beginning of 2013, Zeman, with strong support from the party, became the first directly elected president of the Czech Republic. After the resignation of Prime Minister Petr Nečas (ODS) on 17 June 2013, Zeman decided to transform the SPOZ into a presidential party.

Zeman appointed the so-called technical government led by Jiří Rusnok. Contrary to the composition of the Parliament-the SPOZ had no deputies and only one of 81 senators-a majority in this government had ties to the SPOZ. The government failed to win the confidence of the Parliament, but the President, taking advantage of a constitutional quirk, decided to leave the government in office. The only way for the political parties to block this behavior, which balanced on the edge of the Constitution, was to dissolve the Chamber of Deputies and hold extraordinary elections (Cabada 2013b). In those elections the SPOZ failed. The extraordinary elections in 2013 brought into the Parliament new, and up to now the most successful new political party, clearly based on political personalization, YES 2011 (ANO 2011), formerly the political movement Action of Unsatisfied Citizens 2011 (Akce nespokojených občanů 2011). The movement and subsequent political party were established by one of the most important Czech oligarchs, Andrej Babiš. Within ANO 2011 Babiš played, and continues to play, the predominant role, including control over financial sources for campaigns and operation of the party. Where party membership and candidates were concerned, he often brought in managers from his own companies; in this way he also created a true businessman's party.

5 Although the official name of the party dropped the reference to Zeman (from SPOZ to SPO) at this time, in keeping with common usage, the authors will continue to use SPOZ. 
ANO 2011 did not present clear program for the 2013 parliamentary elections, nor did one come later. Babiš and his supporters offer populist, anti-political rhetoric, criticizing all politicians as cleptocrats and emphasizing that he is not a politician. The state should be run like a firm, according to Babiš. The slogan, Nejsme jako politici, makáme (We're not like politicians, we work) became popular (Havlík et al 2014: 61).

In the parliamentary elections ANO 2011 took second place with 18.65 percent, only 1.8 percent behind the winner, ČSSD. Together with this party and the revived KDU-ČSL they created a government led by Bohuslav Sobotka (ČSSD) with Babiš as first deputy-Prime Minister and Minister of Finance. Meanwhile Babiš added media into his corporate empire, some even before the 2013 parliamentary elections. As Havlík et al (2014: 77) point out, even before the 2013 elections influential Western media, including Der Spiegel and Frankfurter Allgemeine Zeitung were comparing Babiš with Silvio Berlusconi. Similarly, in April 2015 the influential journal Foreign Policy referred to Babiš as "Babisconi." ${ }^{6}$

In the government Babiš has risen to predominance; for some observers it would seem that we have two prime ministers. This matter of fact is strengthened by the behavior of President Zeman, who supports Babiš's ambition to lead in a future one-party government of ANO 2011. Babiš has repeatedly noted that within the coalition he is unable to develop his strategy to run the country as a company, and within the government he is often critical of his coalition partners, referring to them as "traditional parties."

\section{Slovenia}

The Slovenian political space is characterized by a bipolar division into two political blocs (Fink-Hafner 1994; Tomšič 2008; Jou 2011). This division largely covers the left-right cleavage. ${ }^{7}$ This bipolar structure has remained for the whole period, meaning that the right-left division of political space has stabilized considerably (Bebler 2002). However, some changes regarding relationships have taken place within both political camps. In the left-wing camp, Liberal Democracy of Slovenia (LDS) played a leading role throughout most of the transition period, followed by the Social Democrats (SD) and later by Positive

6 Now the Czechs have an Oligarch Problem, http://foreignpolicy.com/2015/04/10/now-the-czechs-have-an-oligarch-problem-too-andrej-babis/ (14 August 2015).

7 The two camps are most clearly divided by their institutional origins and attitudes toward the communist period, with left expressing a positive or at least benevolent attitude toward it while right was highly critical in this regard. The labelling of both political blocs as the left (first camp) and the right (second camp), long used in public discourse, differed from their meanings in the context of Western democracies (to some extent blurring the picture of the Slovenian political space) since members of the business elite are proponents of the left, mostly the LDS, while many of those who considered themselves de-privileged (often described in terms of injustices suffered during the communist regime) have supported the right. 
Slovenija (PS) and now the Modern Centre Party (SMC), although in the case of the latter, the situation is more complicated since it is a recently established party with weak local organization and without a strong ideological core (more on the phenomenon of this party to follow). In the right-wing camp, the leading role was first played by the Slovenian Christian Democrats (the precursor to New Slovenia (NSi)), then by the Slovenian People's Party (SLS), and now, for more than a decade, by the Slovenian Democratic Party (SDS). While in the left-wing camp, the situation was rather stable throughout most of the transition period and has become more volatile in the last few years, in the right-wing camp the situation stabilized at the beginning of the 2000s, with SDS maintaining its dominant position.

In the last couple of years, Slovenian political space has been faced with the rise of a kind of non-party politics (Tomšič - Prijon 2012). This first took place, in fact, at the local level, with the emergence of a number of strong political actors without a previous record in party politics on the political stage. Zoran Janković, a former executive and co-owner of Slovenian retail giant Mercator, who became mayor of Ljubljana in 2006, is the most significant person in this category. Later, the personalized style of politics expanded to the national level. The collapse of the ruling coalition, resulting in the removal of Borut Pahor's left-oriented government (through a vote of no confidence) and subsequent early elections in 2011, brought the rise of a couple of newly formed political parties based strongly on the personalities of their leaders. One of them was Zoran Janković's List-Positive Slovenia (LZJ-PS), led by the mayor of Ljubljana, while the second one was the Civic List of Gregor Virant (LGV), led by the former minister of public administration. ${ }^{8}$ The first surprisingly won a relative majority in the election. However, he didn't become prime minister since Janković failed to form a coalition that would have a majority in the Parliament.

The shelf life of PS was short. After Janković failed to gain a parliamentary majority and form a government (instead of him, Janez Janša became prime minister), his political fortunes declined. At the beginning of 2013, the Slovene Commission for the Prevention of Corruption published its annual report in which it accused both Janković and Prime Minister Janša of non-transparent conduct in respect of their personal finances. As a consequence, Janša's center-rightist government received a vote of no confidence in the Parliament, while Janković wound up resigning as chairman of Positive Slovenia. He was replaced by Alenka Bratušek, who also replaced Janša as Prime Minister and formed a new coalition without Janša's SDS. That caused split in the PS as well as the downfall of her center-left government in May 2014, followed by early elections in July of that year. At these elections, PS was resoundingly defeated-it even fell out of the Parliament (while its successful faction-the Alliance of Alenka Bratušek

8 Both parties withdrew the name of their leader from their official names. 
(ZaAb) - barely managed to get there). The elections were won with a substantial majority by another party newcomer, the Party of Miro Cerar (SMC).

The personalization process of party politics intensified between last two (early) elections. If the two newcomers in the 2011 elections, the LZJ-PS and LGV, each took the name of their leader, in addition to the full name of the party, the names of the last (2014) parliamentary newcomers, the SMC and the $\mathrm{ZaAB}$, are focused solely on their leading figures-although the SMC changed its name after the elections to the Party of Modern Centre (but kept the same acronym-SMC). If the first two parties had clear program orientations, the programs of the latter are characterized by an emptiness. This applied particularly to the winner of the most recent elections, the party formed by a lawyer, Miro Cerar (a professor at the University of Ljubljana), only about a month before the elections, which after the elections switched its name to the Party of Modern Centre (SMC). This absence of substance and consideration was reflected in the brief yet vague electoral program. ${ }^{9}$ This programmatic void was mitigated by criticizing the old political elite on moral and ethical grounds, exposing its past misdeeds. Cerar claimed that his party transcended traditional political and ideological divisions and brought new standards of political culture. Unlike Ljubljana's Mayor Janković, who touted his business experience and related managerial skills, Cerar mobilized support based on his image as highly moral person who has not been contaminated by the dirty antics of his political rivals from the ranks of established political parties. It turned out that a party program was not necessary for electoral success. However, when the party took the leading role in the new government, programmatic fluidity resulted in inconsistent policy orientations that-in combination with the many scandals related to key people from government circles-resulted in a sharp decline in civic support for both the government and its main party.

\section{Factors in the rise of personalized politics}

The rise of a political approach, referred to by some as Berlusconisation ${ }^{10}$ (Mancini 2011), is related to several international developments in contemporary societies. One of them is an increased role for the media in the political process. This is known as the mediatization of politics (Mazzoleni - Schulz 1999; Ginsborg 2005). It applies particularly to the prevalence of media logic in covering political issues and becomes most evident during election campaigns (Swanson -

9 The program of the Party of Miro Cerar was much shorter that the programs of other, more established political parties. In fact, it is a power point presentation, composed of twenty-six slides, with a very general sketch of the party's goals in different areas and guidelines of for its future activities. (http:// mirocerar.si/images/Dokumenti/Program_SMC.pdf)

10 The phenomenon of leadership style known as Berlusconisation is based on the Italian media magnate, politician, and former prime minister, Silvio Berlusconi, who represents a new model of politics, which can be identified in some contemporary democracies. 
Mancini 1996). Modern mass media, especially electronic ones, increasingly build their stories on spectacle, where images play a more important role than ideas and programs (Campus 2015). In such circumstances, it is more vital that a political candidate know how to present himself in front of an audience (supporters, voters) than how relevant or feasible his political proposals are to resolve the political, economic, and social problems.

This development came about in a situation characterized by the poor performance of the established political parties and their governments. The low administrative efficiency of these governments was accompanied by a lack of responsibility on their part (Tomsic - Prijon 2015). They strongly contributed to the weakening of confidence in politics and politicians. The negative view of political institutions-especially political parties, regardless of their ideological orientation-became predominant in the public's assessments (cf. Bull - Newell 2005; Newell 2010). The trend toward a lessening of trust in political institution is evident in many Western democracies but is more profound in the new democracies, such as in the Czech Republic and Slovenia. Among them, political parties are some of the most distrusted (Makarovič - Tomšič 2015; Vráblíková 2009). There are many elements, related to the behavior of established political actors, such as ideologization, incompetence, clientelism, corruption, and other dysfunctional practices that contribute to these negative sentiments. In this climate, new faces are able to gain popularity, especially those who build their campaigns on personalized and sometimes non-political platforms.

There are some personal traits common to most non-partisan politicians. They are, as a rule, strongly extroverted and tend to have direct contact with voters. Simultaneously, they are very skilful in media communication, i.e. the ability to establish an appealing image to the public through the use of visual impressions. They have a great deal of charisma and make followers believe that they can make things better. Their discourse addresses people of a particular country, region or city as a whole rather than a particular social group or constituency based on a specific ideological platform. This approach is often characterized by a strong populism, appealing to ordinary people and claiming to share their thoughts and sentiments. Non-party politicians tend to present themselves as political outsiders with nothing in common with established political structures and who express the genuine will of ordinary people-who are purportedly mistreated at the hands of the old elites. Although they are usually members of the social elite themselves, they nurture an image of themselves as the self-made man who, regardless of his accumulated wealth, thinks and acts like the average Joe. The communication style of these party leaders is plain and energetic. They avoid trying to communicate complicated political messages. Instead, they use simple, straightforward, and often provocative slogans. They are prone to turning their public appearances into spectacles with them playing the protagonists (see Semino - Masci 1994). 
As already mentioned, the Czech Republic and Slovenia used to be perceived as post-communist countries whose political scenes were the most stable, i.e. possessing established political parties that have clear ideological profiles and where political space is dominated by parties of centre-right and centre-left orientations (although with differences in power-relations since, in the Czech Republic, the center-right held power for most of the time, but in Slovenia, this was true for the center-left). However, in the last couple of years, some of the political parties that used to be key political players have weakened or even almost disappeared from the political scene. This was caused by frequent political scandals and a general lack of responsiveness to the needs of the citizenry. They were supplemented by political new-comers who have been building their campaigns either through managerization of politics, based on the notion of politics as business according to which the country should be run as a business firm, or through moralization of politics, i.e. proclaiming a moral renewal of politics and bringing higher standards to political culture. The two approaches are not mutually exclusive. Both have in common a rejection of old political establishment and its allegedly nefarious deeds. However, the irony is that some of these new-comers who loudly denounced their established competitors as corrupt and otherwise problematic, themselves carry heavy baggage in terms of involvement in various suspicious practices (as is evidently the case with Andrej Babiš).

\section{Person-based politics and the functioning of democracy}

A key question in terms of political development of (not only) new democracies is the impact of personalization of politics on the quality of democratic processes. Can the new faces lead to a rejuvenation of political life through a strengthening of political competition and bringing new ideas and higher ethical standards? Can they contribute to more effective policies and thus to a more successful solution to the problems their societies are dealing with?

Personalized leadership can be very effective in mobilizing mass support and overcoming numerous organizational obstacles. A strong and charismatic leader can compensate for a lack institutional structures within a party. However, although such leadership is able to mobilize support in a rather short time, and even win elections, it struggles in keeping support over the long term because of weak institutionalization and no firm policy orientation. The shelf life of personalized parties is thus rather short, which contributes to increased instability in the already volatile political space of the new democracies.

This type of political conduct can be also efficient when carrying out ambitious projects, like building or upgrading infrastructure, etc. However, this holds true mainly at the municipal and regional levels, since the system of governance at this level is not as complex, the leader can more easily exert control over the 
political process. At the national level, this approach proves to be less efficient since, because of these parties' vague programs and lack of clear policy orientation, especially in terms of developmental strategies, the capacity to problem solve is usually limited.

The influence of person-based politics on the democratic process is questionable. This applies particularly to the functioning of political parties. According to Rohrschneider and Whitefield (2012: 2-3), these parties must perform three main functions in order to provide an effective mechanism of representation in contemporary democracies: 1 ) they must offer concrete policy alternatives on relevant issues that structure party systems; 2) they must offer coherent programs, which means that specific positions over different issues are sufficiently interrelated so one can, at least in relative terms, differentiate one policy position from another; and 3) preferences of the citizenry must overlap with the positions of the parties. A party without a clear ideological platform, sound program and consistent policy-orientation can hardly meet any of these three criteria. A party's ability to provide political choice for its citizens is seriously limited. It is true that, based on their personal appeal, political leaders can achieve strong recognition from their supporters. However, this appeal is more often based on populism and demagoguery than on ideas and policy solutions. In this regard, personalization of politics can result in a deterioration of democratic standards.

We can claim that in the cases of the Czech Republic and Slovenia, the rise of person-based political parties and appearance of new faces in political life have brought very few new ideas and concepts and even fewer solutions to the most urgent problems of society. It also didn't induce any evident change in the conduct of established political actors, the very conduct that produced widespread dissatisfaction with politics in general. In this regard, despite high party fluctuation we can't really that they have produced any meaningful increase in political alternatives.

\section{Conclusion}

As we have shown, in the countries under analysis-but basically, this applies generally to many Central and Eastern European countries-personalized politics has played an important role over the last decade(s) and has disrupted the traditional organization of modern democracy based on political parties as repository of collective interests and as the representatives of social groups. This development seems to be-along with many others-one of the products of the decline in the population's willingness to participate in the political party spirit. Such behavior obstructs the ability of political parties to perform one of their traditional functions-to mediate collective interests. In a certain respect, we see a vicious circle: parties do not have the public's trust, but neither are they 
interested in mass membership connected with the development of intra-party democracy and social roots. This, however, is the reason for their inability to articulate relevant social interests, etc. A temporary cure should, according to the notions of some politicians and voters, be new parties, often focused on a single topic. A number of examples can be found in contemporary Central and Eastern Europe. They concentrate on different issues; they use different tools of political marketing; they have different roles in party systems. Yet they do share one thing. In spite of their short-lasting voter and media success, they do not resolve the above-mentioned vicious circle. In their attempts to avoid it, moreover, they are making the situation even worse. Instead of deeply involved social groups as exponents of collective interests, we can observe individual leaders who communicate with voters as if they were consumers of the leaders' products. Such a relationship does not open the door to a democratic discussion, so long as the leader does not accept the basic democratic idea, i.e. that he can be replaced in the party by another person. The party does not present a coherent political program or ideo-political basis; its behavior is limited by the actual decisions and preferences of the leader and, very often, by populism based on public order (many CEE leaders are obsessed with public opinion surveys, adapting themselves according to their results). The authoritative style of managing the party is then also transferred into the executive bodies, which again weakens democracy and democratic control.

One positive outcome of this development might be a transformation of those niche parties with a strong leader and unclear program into a traditional political party with catch-all potential, as in the case of the Slovak Direction (SMER) party and its development into the Direction-Social Democratic (SMER-SD) party. Nevertheless. Also after this domestication, the Slovak Social Democrats are strongly mastered by Robert Fico, the father/grounder and they balance on the edge of social populism and in some cases even welfare chauvinism. This position sits far away from the role of traditional Western Social Democrats. Hopefully, the domestication of the SMC in Slovenia and ANO 2011 as centrist parties in the countries under discussion could produce more promising results, i.e. a transformation into real political parties with adequate party membership, a clear political program and-above all-a real possibility to oppose the party leader, including the possibility of replacing him. Otherwise, the tendencies of illiberal democracy will continue to grow.

\section{References}

Adam, F., Makarovič, M., Rončević, B. and Tomšič, M. (2005): The Challenges of Sustained Development. Budapest, New York: The CEU Press. 
Agh, A. (1996): From Nomenklatura to Clientura: The Emergence of New Political Elites in East Central Europe. In Pridham, G. and Lewis, P. (eds.), Stabilizing Fragile Democracies, London, Routledge, 46-68.

Baylis, T. (1998): Elites, Institutions, and Political Change in East Central Europe: Germany, the Czech Republic, and Slovakia. In Higley J., Pakulski, J. and Wesolowski, W. (eds.), Postcommunist Elites and Democracy in Eastern Europe, London, Macmillan Press Ltd., 107-130.

Bebler, A. (2002): Slovenia's Smooth Transition. Journal of Democracy 13 (1): 127-140.

Beck, U. and Beck-Gertnsheim, E. (2002): Individualization. London: Thousand Oaks, New Delhi: SAGE Publications.

Blondel, Jean; Thiebault, Jean-Louis et al. (2010): Political Leadership, Parties and Citizens. The Personalization of Leadership. Oxon \& New York: Routledge.

Bull, M. J. and Newell, J. L. (2005): Italian Politics. Cambridge: Polity Press.

Bureš, Jan (2012): Volby 2010 v České republice: fenomén nových stran TOP09 a VV. Politics in Central Europe 8 (2): 141-151.

Cabada, Ladislav (2014): Strany mezery v České republice a ve střední Evropě: náčrt možností a limitů politologického výzkumu. In Kubát, Michal; Lebeda, Tomáš et al., O komparativní politologii a současné české politice, Praha, Karolinum, 105-122.

Cabada, Ladislav (2013a): Strany jednoho tématu ve střední Evropě-možnosti a perspektivy politologického výzkumu. In Cabada, Ladislav et al., Strany jednoho tématu ve střední Evropě, Aleš Čeněk, Pilsen, 5-20.

Cabada, Ladislav (2013b): Strany jednoho tématu v českém stranickém systému. In Cabada, Ladislav et al, Strany jednoho tématu ve střední Evropě, Aleš Čeněk, Pilsen, 21-43.

Cabada, Ladislav (2013c): 'Parties with No Members?': How to Ensure Political Participation in East Central Europe, In Demetriou, K.N. (ed.), Democracy in Transition. Political Participation in the European Union, Heidelberg, New York, Dordrecht, London: Springer, 77-94.

Cabada, Ladislav and Krašovec, Alenka (2012). Podobnost institucionálních výběrů a podobnost výsledků? Př́pad Slovinska a České republiky. Politics in Central Europe 8 (2): 52-80.

Campus, D. (2010): Mediatization and Personalization of Politics in Italy and France: The Cases of Berlusconi and Sarcozy. International Journal of Press/Politics 15(2) 219-235.

Carty, R. K. (2004): Parties and Franchise Systems. Party Politics 10 (1): 5-24.

Fink-Hafner, D. (1994): Sindikati v procesu oblikovanja politik. Družboslovne razprave 10 (17-18): 30-47.

Fink-Hafner, D. (1995): Antistrankarsko občutje ob demokratičnem prehodu. In Toš, N. (ed.), Slovenski izziv II, Ljubljana: FDV, 181-204.

Genov, N. (2010): Global Trends in Eastern Europe. Farnham, Burlington: Ashgate.

Ginsborg, P. (2005): Silvio Berlusconi: Television, Power and Patrimony. London, New York: Verso.

Haughton, T. and Deegan-Krause, K. (2015): Hurricane Season: Systems of Instability in Central and East European Party Politics. East European Politics and Societies and Cultures 29 (1): 61-80. 
Havlík, Vlastimil and Vít Hloušek (2013): Czech Political Parties, Their Functions and Performance: Assesing Czech Party Politics. Scientia and Societas 9 (1): 121-43.

Havlík, Vlastimil et al. (2014): Volby do Poslanecké sněmovny 2013. Brno: IIPS and Muni Press.

Hloušek, Vít (2012): Věci veřejné: politické podnikání strany typu firmy. Politologický časopis / Czech Journal of Political Science 19 (4): 322-340.

Hloušek, Vit and Lubomír Kopeček (2012): Záchrana státu? Úřednické a polopolitické vlády $v$ Československu a České republice. Brno: Barrister \& Principal.

Hloušek, Vit and Pavel Pšeja (2009): Europeanization of Political Parties and the Party System in the Czech Republic. Journal of Communist Studies and Transition Politics 25 (4): 513-39.

Hopkin, J. and Paolucci, C. (1999): The business firm party model of party organisation: Cases from Spain and Italy. European Journal of Political Research 35 (3): 307-339.

Inglehart, R. (1990): Cultural Shift in Advanced Industrial Society. Princeton: Princeton University Press.

Innes, A. (2002): Party Competition in Postcommunist Europe: The Great Electoral Lottery. Comparative Politics 35 (1): 85-104.

Janos, A. (2000): East Central Europe in the Modern World. Stanford University Press, Stanford.

Jou, W. (2011): Left-Right Orientations and Ideological Voting in New Democracies: A Case study of Slovenia. Europe-Asia Studies 63 (1): 27-47.

Jurek, Petr (2014): Oligarchizace, personalizace a prezidencializace v soudobých demokraciích. Kritická reflexe konceptů a analýza českého př́padu. Doctoral Dissertation, Dept. of Politics and International Relation, University of West Bohemia in Pilsen/Czech Republic, 201 p.

Kaase, M. (1994): Is There Personalization in Politics? Candidates and Voting Behavior in Germany? International Political Science Review / Revue internationale de science politique 15 (3): 211-230.

Karvonen, Lauri (2010): The Personalization of Politics. A Study of Parliamentary Democracies. Colchester: ECPR Press.

Katz, Richard S. and Mair, Peter (1995): Changing Models of Party Organization and Party Democracy: the Emergence of the Cartel Party. Party Politics 1 (1): 5-31.

Kitschelt, H. (2001): Divergent Paths of Postcommunist democracies. In Diamond, L. and Gunther, R. (eds.), Political parties and Democracy, Baltimore, The Johns Hopkins University Press, 299-323.

Krašovec, Alenka and Cabada, Ladislav (2013): Kako smo si različni: značilnosti vladnih koalicij v Sloveniji, Češki republiki in na Slovaškem. Teorija in praksa 50 (5-6): 23-41.

Kriesi, H.-P. (2011): Personalization of national election campaigns. Party Politics 18 (6): 825-844.

Krouwel, André (2006): Party Models. In Katz, R. S. - Crotty, W. (eds.), Handbook of Party Politics, London, Thousand Oaks, New Delhi: Sage, 249-269.

Makarovič, M. and Tomšič, M. (2015): Democrats, authoritarians and nostalgics: Slovenian attitudes toward democracy. Innovative issues and approaches in social sciences 8 (3): 8-30. 
Mancini, P. (2011): Between Commodification and Lifestyle Politics: Does Silvio Berlusconi provide a new Model of Politics for Twenty-First Century? Oxford: Reuters Institute for the Study of Journalism.

Mazzoleni, G. and Schulz, W. (1999): Mediatization of Politics: A Challenge for Democracy. Political Communication 16: 247-61.

Meguid, B. M. (2007): Party Competition between Unequals. Strategies and Electoral Fortunes in Western Europe. Cambridge University Press.

Newell, J. L. (2010): The Politics of Italy. Cambridge: Cambridge University Press.

Now the Czechs have an Oligarch Problem, http://foreignpolicy.com/2015/04/10/now-the-czechs-have-an-oligarch-problem-too-andrej-babis/ (14 August 2015).

Olteanu, Tina and de Nève, Dorotheé (non dated): Business Firm or rather Businessman Parties? Political Entrepreneurs in Action, available at http://paperroom.ipsa.org/papers/paper_33739. pdf (2 May 2016).

Poguntke, Thomas and Webb, Paul (2005a): The Presidentialization of Politics in Democratic Societies: A Framework for Analysis. In Poguntke, T. And Webb, P. (eds.), The Presidentialization of Politics: A Comparative Study of Modern Democracies, Oxford and New York, Oxford University Press, 1-25.

Poguntke, Thomas and Webb, Paul (2005b): The Presidentialization of Contemporary Democratic Politics: Evidence, Causes, and Consequences. In Poguntke, T. And Webb, P. (eds.), The Presidentialization of Politics: A Comparative Study of Modern Democracies, Oxford and New York, Oxford University Press, 336-355.

Potůček, M. (1997): Těžké znovuzrození: občanský sektor v České republice. Politologická revue 3 (2): 35-52.

Rahat, G. and Sheafer, T. (2007): The Personalization(s) of Politics: Israel 1949-2003, available at: http://eshkol.huji.ac.il/doc/Gideon\%20Rahat-Tamir\%20SheaferThe\%20Personalization\%20 of\%20Politics\%20lsrael\%201949-2003.pdf (11 August 2015).

Rohrschneider, R. and Whitefield, S. (2012): The Strain of Representation. Oxford: Oxford University Press.

Sartori, G. (1976) Parties and party systems. Cambridge: Cambridge University Press.

Semino, E. and Masci, M. (1996): Politics is Football: Metaphor in the Discourse of Silvio Berlusconi in Italy. Discourse \& Society 7 (2): 243-269.

Swanson, D. and Mancini, P. (eds.) 1996. Politics, Media and Modern Democracy. Westport, CT: Praeger.

Tavits, M. (2008): Party Systems in Making: The Emergence and Success of New Parties in New Democracies. British Journal of Political Science 38 (1): 113-133, doi http://dx.doi.org/10.1017/ S0007123408000069.

Tomšič, M. (2008): Historical development of slovenian political elite. Innovative issues and approaches in social sciences 1(2): 47-66.

Tomšič, M. and Prijon, L. (2013): Person-based politics in Italy and Slovenia : comparing cases of leadership's individualization. International Social Science Journal 64 (213/214): 237-248. 
Van Biezen, I. (2003): Political Parties in New Democracies. Party Organization in Southern and East-Central Europe. Palgrave Macmillan, Houndmills.

Van Zoonen, L. and Holtz-Bacha, C. (2000): Personalization in Dutch and German Politics: The Case of Talk Show. Javnost-The Public 7 (2): 45-56.

Vodička, Karel and Cabada, Ladislav (2011): Politický systém České republiky. Portál: Prague.

Vráblíková, K. (2009): Politická participace a její determinanty v postkomunistických zemích. Sociologický časopis/Czech Sociological Review, 45 (5): 867-897.

Wagner, M. (2012): Defining and measuring niche parties, available at http://homepage.univie. ac.at/markus.wagner/Paper_nicheparties.pdf (3 September 2015).

Whitefield, S. and Evans, G. (1998): Electoral Politics in Eastern Europe: Social and Ideological Influences on Partisanship in Post-Communist Societies. In Higley J., Pakulski, J. and Wesolowski, W. (eds.), Postcommunist Elites and Democracy in Eastern Europe, London, Macmillan Press Ltd., 226-250.

Ladislav Cabada is Associated Professor of Political Science at the Metropolitan University Prague/Czech Republic. In the academic year 2016/17 he holds the position of International Chair at the National University of Public Service (Nemzeti Köszolgálati Egyetem) in Budapest/Hungary. He acts also as co-editor of the Politics in Central Europe. The Journal of Central European Political Science Association. Since 2012 he has been working as the President of Central European Political Science Association (CEPSA). E-mail: ladislav.cabada@mup.cz

Matevž Tomšič is political sociologist and Professor at the School of Advanced Social Studies in Nova Gorica, Faculty of Information Studies in Novo mesto and Faculty of Media in Ljubljana. His research interests include: political elites and political leadership, quality of governance, political culture, Europeisation, democratisation and development of societies from Central and Eastern Europe. Among others, he recently published a book Elites in the New Democracies (Peter Lang, 2016). He is also co-author of book The Challenges of Sustained Development (Central European University Press, 2005).E-mail: matevz.tomsic@fuds.si 